International Journal of Current Advanced Research

ISSN: O: 2319-6475, ISSN: P: 2319 - 6505, Impact Factor: SJIF: 5.995

Available Online at www.journalijcar.org

Volume 6; Issue 5; May 2017; Page No. 3578-3581

DOI: http://dx.doi.org/10.24327/ijcar.2017.3581.0319

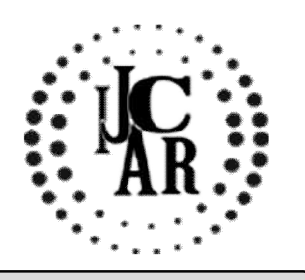

Research Article

\title{
ANTICARCINOGENIC ACTIVITY OF SOLANUM TRILOBACTUM ON ORAL CELL LINES
}

\author{
Aparnaa.M and Geetha RV
}

Saveetha Dental College; Chennai

\begin{tabular}{l}
\hline A R T I C L E I N F O \\
\hline Article History: \\
Received $15^{\text {th }}$ February, 2017 \\
Received in revised form $12^{\text {th }}$ March, 2017 \\
Accepted $18^{\text {th }}$ April, 2017 \\
Published online $28^{\text {th }}$ May, 2017
\end{tabular}

\section{Key words:}

Oral cancer cell lines, solanum trilobactum, c6ell metabolic activity, anticarcinogens, phytochemical activity. \begin{abstract}
A B S T R A C T
Aim and Objective: To asses the anti-carcinogenic activity of solanum trilobactum on oral cell lines.

Background: Solanum trilobactum is one of the common Indian medicinal plants and it has been used in traditional medicine for many centuries. It consist of all the important nutrients required for the body. The plant possess a broad spectrum of antibiotic, antibacterial and anticancer activity. The main objective is to study the effect of anticarcinogenic activity of solanum trilobactum on oral cell lines.

Method: Assessment of anti-carcinogenic activity of solanum trilobactum towards oral cell lines was done by MTT calorimetric assay. The MTT assay is a colorimetric assay for assessing cell metabolic activity.

Result: The percentage of cell inhibition on the oral Cell line was about 75 while the concentration of the solanum trilobactum was 400 microgram $/ \mathrm{ml}$.
\end{abstract}

Copyright $₫ 2017$ Aparnaa.M and Geetha $\boldsymbol{R V}$. This is an open access article distributed under the Creative Commons Attribution License, which permits unrestricted use, distribution, and reproduction in any medium, provided the original work is properly cited.

\section{INTRODUCTION}

Oral cancer (Malignant tumour) is an abnormal growth and proliferation of cells which occurs in the oral cavity. It is a frightful disease because the patient suffers pain, disfigurement and loss of many physiological processes. Cancer may be uncontrollable and incurable and may occur at any time at any age in any part of the body. It is caused by a complex poorly understood interplay of genetic and environmental factors. It continues to represent the largest cause and kills about 1500 per million populations annually around the world. (6)

Oral cancer is a major public health burden in estimated that there were 10.9 million new cases 6.7 million deaths and 24.6 million persons living with cancer around the world in 2002. Cancer is the second leading cause of death in the United States where one in four deaths is due to cancer. Plants have long been used in the treatment of cancer. The systematic anticancer remedies are beyond the reach of common man because of cost factor.(15) Squamous cell cancers are common in the mouth, including the inner lip, tongue, floor of mouth, gingivae, and hard palate. Cancers of the mouth are strongly associated with tobacco use, especially use of chewing tobacco or "dip", as well as heavy alcohol use. Cancers of this region, particularly the tongue, are more frequently treated with surgery than are other head and neck cancers.

*Corresponding author: Aparnaa.M

Saveetha Dental College; Chennai
A large number of chemopreventive agents are used to cure various cancers, but they cause side effects that prevent their extensive usage. Although more than 1500 anticancer drugs are in active development with over 500 of the drugs under clinical trials. There is an urgent need to develop much effective and less toxic drugs.

Anticarcinogens are different from anticarcinoma agents (also known as anticancer or anti-neoplastic agents) in that anticarcinoma agents are used to selectively destroy or inhibit cancer cells after cancer has developed. Interest in anticarcinogens is motivated primarily by the principle that it is preferable to prevent disease (preventive medicine) than to have to treat it (rescue medicine). (4)

According to Encyclopaedia of world medicinal plants, a plant is said to possess, anti-carcinogenic, anti-bacterial, antifungal, anti-mitotic (that stops cell growth by cell division) and anti-tumour activities.

Plants have a long history of use in the treatment of cancer hartwell in his review of plants used against cancer, lists more than 3000 plants species that have reportedly been used in the treatment of cancer. In many instances, however, the cancer "is undefined, or reference is made to condition such as "hard swelling" abscesses, callues, corns, warts, polys, or tumors to have a few, these symptoms would generally apply to skin tangible or visible condition, and may indeed sometimes corresponds to a conditions. The search for anticancer agents from plant source started in earnest in the $1950 \mathrm{~s}$ with the discovery and development of the vinca, alkaloids, vinblastin and vincristine, and the isolation cytotoxic 
podophyllotoxin. (7) Although many anticancer compounds such as alkaliating compounds anti metobiltes, redimimetics, hormones and antagonist have been developed. None of them give satisfaction and no side effects. The world health organization estimates that approximately $80 \%$ of the world's inhabitants regular on traditional medicine of their primary health care.

Herbal medicines have a vital role in the prevention and treatment of cancer and medicinal herbs are commonly available and comparatively economical. Chattisgarh has been declared as the Herbal State of India.

Herbal treatment proves its efficacy in medicinal field without any side effects as synthetic medicines have; hence it's preferred to be more beneficial.(11,3)

Plant extracts has the ability of activating the apoptotic pathway of cancer cells and doesn't have any ethical issues when it is used as drug formulations as it is purely herbal.

The use of traditional medicine and medicinal plants in most developing countries, as a normative basis for the maintenance of good health has been widely observed (UNESCO, 1996). Furthermore, an increasing reliance on the use of medicinal plants in the industrialized societies has been traced to the extraction and development of several drugs, chemotherapeutics from these plants as well as from traditionally used rural herbal remedies. (5)

The results of investigation performed in the 19 and 20th century and the advent streptomycin and other antibiotics provide the ground for experimentation of a vast of plants for antibiotic or antimicrobial activities that are useful to man. The genus Solanum was established by Carl Linnaeus in 1753. Solanum trilobatum (Solanacea) is a thorny shrub widely distributed in Bengal, Utterpradesh, Southern India and Srilanka in moist place. This plant is well known in Ayurvenda and Siddha system as "Alarka" and Tuduvelai; respectively. The sidda system of medicine uses a ghee prepared from this plant for treatment of tuberculosis. Solanum trilobatum, a thorny creeper with bluish violet flower, more commonly available in southern India. Solanum trilobatum (Solanaceae-herbs) is an amount of calcium, iron, phosphors, carbohydrates, fat, crude fiber and minerals in the leaves.(7)

The leaves of Solanum trilobatum revealed the presence of Sugars, Protein, Alkaloids, Flavonoids, Saponins, Tannins, Cardiac glycosides, Terpenoids and Lipids. The root bark is laxative, useful in the treatment of ulcers on the neck, burking of thwart, inflammation of liver and chronic fever. Berries are bitter and pungent useful in the heart disease, piles and dysentery. Roots, berries and flowers are used for cough. The solanum trilobatum commonly used in traditional medicine because of its derivate having antipyretic effects, and has a long history of use in the treatment of inflammation, edema, martitis, cirrholis, of liver in oriental medicine. The whole plant of Solanum trilobatum contains many steroidal glycosides, steroidal alkaloids, polyphenols, flavanoids, fatty acids and essential oils.(4)

This herbal plant is used as medicine for asthma, vomiting of blood, reducing blood glucose level and bilious matter phlegmatic rheumatism and several kinds of leprosy it is also anti-carcinogenic,antibacterial, antifungal, antimitotic, and antioxidant activity.(6)

Phytochemical analysis of Solanum trilobatum extract was conducted. By this analysis, the presence of several phytochemical like sugar, protein, alkaloids. The present study reveals the determination of anticancer activity of Solanum trilobatum in oral cell lines .(9)

\section{MATERIALS AND METHOD}

The leaves of Solanum trilobatum (Solanaceae) were collected during the month of December 2016 from Chennai.

\section{MTT ASSAY}

The MTT assay is a colorimetric assay for assessing cell metabolic activity. NAD(P)H-dependent cellular oxidoreductase enzymes may, under defined conditions, reflect the number of viable cells present. These enzymes are capable of reducing the tetrazolium dye MTT 3-(4,5dimethylthiazol-2-yl)-2,5-diphenyltetrazolium bromide to its insoluble formazan, which has a purple color. With WST-1, which is cell-impermeable, reduction occurs outside the cell via plasma membrane electron transport. Tetrazolium dye assays can also be used to measure cytotoxicity (loss of viable cells) or cytostatic activity (shift from proliferation to quiescence) of potential medicinal agents and toxic materials. MTT assays are usually done in the dark since the MTT reagent is sensitive to light.

\section{Experimental procedure}

Cancer cells HT-29 were trypsinized. Then $5 \mathrm{ml}$ of growth medium was added to trypsinized cells and cell suspension was mixed well. Then $2 \mathrm{ml}$ of cell suspension was added to the sterilized test tubes containing cover slip. The test tubes were placed in a slanting position and kept in $\mathrm{CO} 2$ incubator for two days. The monolayer of cells formed in the cover slip was observed under light microscope and photographed.

Phytochemical tests The various photochemical tests were performed to know the active components present in the Solanum trilobatum such as alkaloids, flavonoids, sugars, glycosides, spannins, tannins, proteins, aminoacids, terpenoids.

\section{Assessment of anti-carcinogenic activity of solanum trilobactum towards oral cell lines by MTT calorimetric assay}

Sensitivity of KB [Oral squamous cell carcinoma] cells to solanum trilobactum was determined individually by the MTT colorimetric assay. Cells were seeded in a flat-bottomed 96well plate and incubated for $24 \mathrm{~h}$ at $37^{\circ} \mathrm{C}$ and in $5 \% \mathrm{CO} 2$. Cell lines were exposed to the plant extract at different concentrations. The solvent DMSO treated cells served as control. Cells were then treated with MTT reagent (20 $\mu \mathrm{l} /$ well $)$ for $4 \mathrm{~h}$ at $37^{\circ} \mathrm{C}$ and then DMSO $(200 \mu \mathrm{l})$ was added to each well to dissolve the formazan crystals. The optical density (OD) was recorded at $492 \mathrm{~nm}$ in a microplate reader. Percentage of residual cell viability was determined as [1(OD of treated cells/OD of control cells) $] \times 100$.

\section{Statistical analysis}

Statistical analysis of the data was performed with Student's t-test. Differences with P-values were considered to be 
statistically significant $(* \mathrm{P}<0.05, * * \mathrm{P}<0.01, * * * \mathrm{P}<0.0001$ versus control)

\section{Effect of Solanum trilobactum on KB cell}

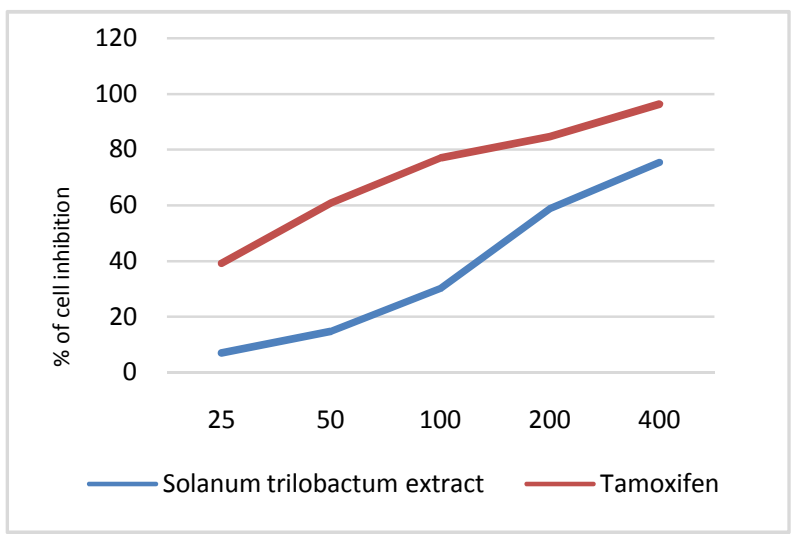

\section{RESULT}

The percentage of cell inhibition on the oral Cell line was about 75 while the concentration of the solanum trilobatum was $400 \mathrm{microgram} / \mathrm{ml}$.

Percentage of cell inhibition on KB cell line:

\begin{tabular}{ccc}
\hline $\begin{array}{c}\text { Concentration of the } \\
\text { extract } \boldsymbol{\mu} \mathbf{g} / \mathbf{m l}\end{array}$ & \multicolumn{2}{c}{ of cell inhibition } \\
\hline & $\begin{array}{c}\text { Solanum } \\
\text { trilobactum } \\
\text { extract }\end{array}$ & Tamoxifen \\
\hline 25 & 7.05 & 39.25 \\
50 & 14.78 & 60.98 \\
100 & 30.25 & 77.05 \\
200 & 58.74 & 84.70 \\
400 & 75.40 & 96.35 \\
\hline
\end{tabular}

\section{DISCUSSION}

The genus Solanum (Solanaceae) is a rich source of steroidal glycoalkaloids. The plant of this genus mainly contain sterol alkaloids like solamargine, solasonine and solanine and steroidal sapogenins, diosgenin and diosgenone, solanine, isolated from Solanum species, has been reported to induce apoptosis in cell, by inhibiting the expression of protein. Another steroidal alkaloid, solamargine has also been report to exhibit the anti-tumor effects. It was previously reported that solamargine and solasodine are cytotoxic to cell.since both Solamargine and solanine reduced the viability of cells, where as p2-solamargine was inactive. $(6,7)$

Saponins are an important class of secondary metabolites which have been long recognized to show cytotoxic activity in various cancers cell lines. Apoptosis in an attractive endpoint of cancer therapy. (6)

The anticarcinogenic activity and tumor growth inhibitory effect of Sobatum from Solanum trilobatum formed the basis for the assessment on the role of Solanum trilobatum on DEN induced hepatocarcinogenesis. The decrease in TSP observed in ccl4 treated rats may be associated with the decrease in the number of hepatocytes which in turn may result into the decrease hepatic capacity to synthesise protein, but the restoration of the level of TSP after the administration of STE conformed the hepatoprotective nature of Solanum trilobatum. The ethyl acetate extract only contains flavonoids and tannin. It was estimate that the presence of quinine compound in n-Butanol extract in inhibiting cancer cell growth compared by ethyl acetate extract. The anticancer activity of this plants is due to the presence of antioxidants i.e., polysachharides, polyphenols, flavonoids, lignins, xanthones. There is a broad scope to derive the anticancer agent from medical plants, which needs thorough research.(13)

The herbs were helpful against cancer, those outcome require for the conformation with rigorously control the trial particularly herbs are very much useful improving survival and quality of life in patient suffering from advanced cancer(2).

\section{CONCLUSION}

The percentage of cell inhibition on the oral Cell line was about 75 while the concentration of the solanum trilobatum was 400 microgram $/ \mathrm{ml}$. Therefore the values considered above were significant under statistical analysis.

\section{References}

1. Vishnu Priya Veeraraghavan surepneni Krishna Mohan*, Mallika Jainu Ameliorating effects of Garcinia mangostana Linn pericarp extract on hepatic antioxidants in Diethyl nitrosamine (DEN) induced Hepatocellular Carcinoma (HCC) Indian Journal of Pharmaceutical Education and Research | Vol 49 | Issue 4 | Oct-Dec, 2015.

2. Shruthi Chandrasekaran Role Of Tannins In Oral Health CARE International Journal of Pharmaceutical Science and Health Care Issue 4, Vol. 3.May-June 2014

3. Vishnupriya; Surepneni Krishna Preliminary Phytochemical Analysis And Oral Acute Toxicity Study Of The Root Of Argemone Mexicana Linn. February - March, 2016, Vol. 5, No.2, pp 2010-2017

4. T.Meera; DNA FRAGMENTATION ; Pharm. Sci. \& Res. Vol. 8(10), 2016, 1188-1190 Journal of pharmaceutical sciences .jpsr

5. Keerthana B1*, Gayathri R2, Vishnu Priya V2 Apoptotic induction potentials of bacopa moneri against oral Cancer cell line.Vol 12;ISSUE 2/2016.,234-241

6. Senthil Kumar B1*, Antimicrobial And Antioxidant Activity of Cycas Circinalis L. And Ionidium Suffruticosum Ging Vol 5, Issue 1, 2017 ISSN - 23214406

7. Tiwari AK. Imbalance in antioxidant defence and human diseases: Multiple approach of natural antioxidant therapy. Curr Sci 2001; 81:1179.

8. Kumar SB, Kumar VJ. Effect of Ionidium suffruticosum on testes of young albino rats. Int $J$ Pharm Biol Sci 2012;2(3):106-12.

9. Kumar SB, Kumar VJ, Selvaraj R. An acute oral toxicity of Cycas circinalis and Ionidium suffruticosum on wister Albino Rats. Int J Pharm Sci Rev Res 2012; 17(2):97-100.

10. Baur AW, Kirby WM, Sherris JC, Turck M. Antibiotic susceptibility testing by a standard single disk method. Am J Clin Pathol 1966; 45(4):493-6. 
11. Khalaf NA, Shakya AK, Al-Othman A, El-Agbar Z, Farah H.Antioxidant activity of some common plants. Turk J Biol 2008; 32:51-5.

12. Harman D. Aging: Phenomena and theories. Ann $N Y$ Acad Sci 1998; 854:1-7.

13. Cai Y, Sun M, Corke H. Antioxidant activity of betalains from plants of the amaranthaceae. J Agric Food Chem 2003; 51(8):2288-94.
14. Zheng W, Wang SY. Antioxidant activity and phenolic compounds in selected herbs. J Agric Food Chem 2011; 49(11):5165-70.

15. Rice-Evans CA, Miller NJ, Bolwell PG, Bramley PM, Pridham JB. The relative activities of Plant derived polyphenolic flavonoid. Free Rad Res 1995; 22(4):37583.

\section{How to cite this article:}

Aparnaa.M and Geetha RV (2017) ' Anticarcinogenic Activity Of Solanum Trilobactum On Oral Cell Lines', International Journal of Current Advanced Research, 06(05), pp. 3578-3581.

DOI: http://dx.doi.org/10.24327/ijcar.2017.3581.0319 